\title{
7075-T6 A1 押出し材の疲労特性に及ぼす組織の影響
}

\section{Effects of Microstructures on Fatigue Properties of Extruded 7075-T6 Al Alloy}

\author{
○竹中 真迪（鹿児島大学） \\ 大坪 伸二 (鹿児島大学 (現 住友軽金属)) \\ 西 祐希 (鹿児島大学 (現 サッマ酸素工業)) \\ 正 中村祐三（鹿児島大学） \\ 正 皮籠石 紀雄（第一工業大学） 正 仮屋 孝二（第一工業大学）
}

\begin{abstract}
Masamichi TAKENAKA, Kagoshima University, korimoto 1-21-40, kagoshima-shi, Kagoshima Yuki NISHI, Satsuma Sanso Kougyou Co., Ltd., tokaicho 3-42, kagoshima-shi, Kagoshima Shinji OTUBO, Sumitomo Light Metal Industries Ltd., sennen 3-1-12, minato-ku, nagoya-shi, Aichi Yuzo NAKAMURA, Kagoshima University, korimoto 1-21-40, kagoshima-shi, Kagoshima Norio KAWAGOISHI, Daiichi Institute of Technology, kokubuchuo 1-10-2, kirishima-shi, Kagoshima Kohji KARIYA, Daiichi Institute of Technology, kokubuchuo 1-10-2, kirishima-shi, Kagoshima
\end{abstract}

Key Words: 7075-T6 $\mathrm{Al}$ alloy, fatigue properties, microstructure.

\section{1. 緒論}

時効硬化形 $\mathrm{Al}$ 合金は高強度を有し, 軽量であることから, 航空機等, 軽量性, 高比強度を望まれる様々な分野において 利用され，特に， $\mathrm{Al}$ 中に $\mathrm{Zn}, \mathrm{Mg}, \mathrm{Cu}$ を添加した 7000 系合 金はもっとも優れた強度をもつ有用な材料である。一方，こ うした $\mathrm{Al}$ 合金の疲労特性は腐食環境下において劣化し，大 気中の湿度が高い場合にも疲労強度が低下寸る。筆者らの以 前の 7075-T6 押出し材の疲労特性に関寸る研究 1)では, 回転 曲げ疲労試験, また高サイクル疲労特性を調べるために用い た超音波疲労試験のいずれにおいても，相対湿度（以下 RH） が $60 \%$ 以上において疲労強度が乾燥雾囲気の場合よりも半 分近く减少することを明らかにしている.また，このような 高湿度雾囲気中における疲労強度劣化には, 高速で伝ぱする せん断形のき裂進展が密接に関わっており，せん断形き裂の 方向は，荷重軸に対して常に $35^{\circ}$ の角度をなし，試験片全体 に及ぶこともあることがわかっている。

これまでの研究では，このような 7075-T6 押出し材の高 湿度雾囲気中における疲労強度の低下は, $\mathrm{Al}$ 表面において大 気中の水分子が反応して形成された $\mathrm{H}$ 原子の一部が, 材料内 に拡散して転位の運動を促進し, 低応力で塑性変形を助長す る水素促進局所塑性変形 (以下 HELP) が原因と考えている. しかし，多結晶材料において巨視的なすべり方向が一定とな るわけでなく, 押出し材特有の集合組織がせん断形き裂の形 成・進展を助長していると考えている. 一方, 素材の加工, 熱処理の履歴, あるいは疲労試験の条件によって必ずしも, 高湿度特有のせん断形き裂が形成されない場合もあること がわかってきた ${ }^{2)}$.このことから, 高湿度骞囲気中で強度劣 化を示す押出し材のき裂伝ぱと集合組織の関係を明らかに することは,こうした違いに関して知見を得る上で重要であ る.

本研究では, これまで得られている高湿度雾囲気下におけ る 7075-T6 Al 押し出し材の疲労特性について組織の影響を 調べることを目的として，電子後方散乱回折（以下 EBSD） ならびに X 線回折（以下 XRD）を用いて押出し組織につい て調べ, せん断形き裂の結晶学的幾何学について検討した。

\section{2. 実験方法}

本実験で用いた 7075-T6Al 押出し材は, 既に前の研究 1)，2) で疲労特性が詳細に調べられたものであり, その組成は Table 1のようになっている. 試験片は, 市販材を改めて 733 $\mathrm{K}$ の温度で $10.8 \mathrm{ks}$ の時間保持して溶体化処理を行った後, $393 \mathrm{~K}$ で $86.4 \mathrm{ks}$ の T6 時効処理が施している. この T6 処理 による引張特性は, 降伏強度 $527 \mathrm{MPa}$, 引張強さ $673 \mathrm{MPa}$, 絞り $11.3 \%$ となっており, 市販材の降伏強度 $630 \mathrm{MPa}$, 引張 強さ $691 \mathrm{MPa}$ よりも強度が減少した. 疲労試験は, Fig. 1 に 示寸形状・寸法の試験片を用い, 室温で RHを $0 \%$ 100\%で 変化させて, $50 \mathrm{~Hz}$ の回転曲げによって行った.このとき, $0 \%$ RH は窒素雲囲気中の試験, $100 \% \mathrm{RH}$ は蒸留水中の試験であ る. EBSD ならびに XRD の解析は, 上記の再溶体化・T6 時 効材に加えて, 比較のため市販材, ならびに $773 \mathrm{~K}, 118.8 \mathrm{ks}$ で再溶体化し同じ $\mathrm{T} 6$ 時効を施した試験片についても行った。 EBSD は電界放出形走査電子顕微鏡（Hitachi，SU-70）に取 り付けられた EBSD 解析装置（Edax, GE-1）を用いて行い, 押出し材の横断面ならびに縦断面の組織を調べた. 用いた加 速電圧は $15 \mathrm{kV}$ である. なお, EBSD 観察面は切断後, ペー パー研磨, ダイヤモンド研磨, $20 \mathrm{~nm}$ のシリカパウダーによ る研磨を順次行い, さらに $50 \mathrm{eV}$ 程度の低エネルギー $\mathrm{Ar}$ イオ ンによる仕上げを行っている，また，XRD解析は， EBSD 解 析を終えた表面について, 高速 X 線回折装置 (PANalytical, X'Pert PRO MPD）により Cu Ka線を用いて行った。

\section{3. 実験結果及び考察}

Fig. 2 は, 降伏強度 $\sigma_{y}$ を基淮応力として态力振幅 $\sigma_{a}$ を規 格化した $S N$ 曲線である。また図中の曲線は,

$$
\sigma_{a}=\sigma_{a o}+k\left\{\left(N_{f} / N_{f o}\right)^{-m}-1\right\}
$$

を用いて表したものである.ここで $k, m$ は定数であり， $N_{f o}$ は $10^{7}$ とし， $\sigma_{a o}$ は $10^{7}$ 回での耐久限度となる。これより，

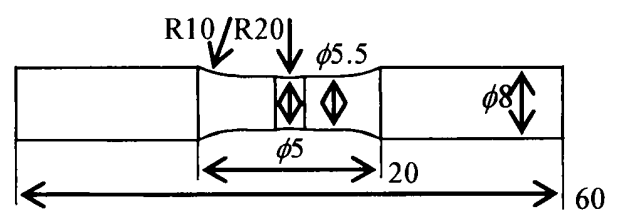

Fig. 1 Shape and size of specimen $(\mathrm{mm})$.

Table 1. Composition of 7075-T6 Al.

\begin{tabular}{cccccccccc}
\hline \hline Element & $\mathrm{Zn}$ & $\mathrm{Mg}$ & $\mathrm{Cu}$ & $\mathrm{Cr}$ & $\mathrm{Si}$ & $\mathrm{Fe}$ & $\mathrm{Mn}$ & $\mathrm{Ti}+\mathrm{Zr}$ & $\mathrm{Al}$ \\
\hline Mass fraction (\%) & 5.46 & 2.56 & 1.47 & 0.19 & 0.09 & 0.25 & 0.03 & 0.03 & bal. \\
\hline \hline
\end{tabular}

日本機械学会講演論文集 No. $1338-1$ [ $13-3-13$, 九州支部第 66 期総会講演会 $]$ 
$50 \%$ 以下の相対湿度では $S N$ 曲線はほぼ同様であるが，こ れ以上になると疲労強度は低下し，特に $85 \%$ RH 以上で減 少が大きく，蒸留水中では耐久限度は降伏強度の $18 \%$ まで 低下寸る，破壊の形態も湿度の影響を受け，Fig. 3(a)のよう に低湿度の場合には引張形のき裂が生じてせん断形へ遷移 するのに対し，高湿度では, Fig. 3(b)のように, 高応力レ ベルでせん断形のき裂が生じて発達する傾向がある.一方， 高湿度䨌囲気であっても低応カレベルでは巨視的に引張形 の破壊モードとなるが，表面にせん断形き裂が多数形成さ れて合体した結果であると考えられる．Fig. 3(b)より，せ ん断形き裂の発生は荷重軸に対して傾いており，その角度 は $35^{\circ}$ であった。この幾何学的特徵はせん断形でき裂が伝 ぱするときも同じであった。

Fig.4(a)，(b)はそれぞれ，EBSD 解析により横断面におけ る表面に垂直な方向と平行な方向の結晶方位を表した IPF マップである．横断面は約 $80 \%$ が法線が<111>に近い結晶 粒（以下<111>粒）で占められ，残りは<001>方位に近い粒 (以下 $<001>$ 粒) で占められていた。 またこれらの粒内は 多数の亜粒界が存在することがわかる．亜粒界を含めない ときの粒径は約 $12 \mu \mathrm{m}$ であり，含めたときには $3.9 \mu \mathrm{m}$ とな った。一方，縦断面を観察すると押出し方向には<111>方 位の結晶粒が占めていることがわかる（Fig. 4(c)）。ただし この場合にも詳細に見ると亜粒界が多数含まれている（Fig 4(d)). 再溶体化処理を行ってない供試材では同じ疲労試験 条件で, 窒素雾囲気を除き，引張形の破壊が生じることが わかっているが 2), この試験片では<111>粒の割合は $61 \%$ であり，粒径も小さかった。このことより，せん断形き裂 の形成と伝ばは，再溶体化処理で $<111>$ 粒が優先的に成長 したこと，ならびに，<111>粒の優先的な配向がせん断形 き裂の発生・伝ぱと密接に関わっていることが考えられる. また縋断面の $<001>$ 粒を見ると，周りの<111>粒と結晶方位 が連続的に慗がっている箇所があることがわかる。このこ とから，方位が連続した $<001>$ 粒と<111>粒では方位が共通 する特定のすべり系が容易に伝ぱすると考えられる.

同様の集合組織の特徴は XRD 解析でも得られたが，供 試材では XRD ピークの幅が広がっているのに対して，再 溶体化材では狭まっていた（Fig. 5)。このことは，供試材 では大量の転位が含まれていたものが，再溶体化処理によ って著しく低減されたことを示唆している。また，供試材 では疲労試験中に既存の多量の転位がそれぞれのすべり面 に沿って運動するが，再溶体化処理材では増殖される転位 が上述した<111>粒の優先組織において特定のすべり面を 運動するものと考えられる.高湿度雾囲気ではこうした集 合組織に従う選択的なすべり系が活動において, HELP 機 構によって転位の運動が助長されると考えられる。

破面のエッチピット観察から，せん断形き裂は $\{100\}$ 面に おいて<011>方向に進展することがわかっている ${ }^{2)}$. 本研究 で得られた EBSD 解析の結果を用いて結晶学的な幾何学を 検討すると，このようなせん断形亀裂伝ぱの結晶学的特長 は，<111>粒内の二つのすべり面においてそれと交わるす ベり方向に等価なすべりが発生した場合に生じることによ ることが示唆される.また表面に現れるV 字形の対称的な せん断き裂の発生は<001>粒内での二つのすべり系が働い た場合に起こりえることが示唆される.

\section{4. 結論}

7075-T6 押出し材の高湿度䨌囲気における疲労強度の劣 化に伴うせん断形き裂の発生原因について，EBSD ならび

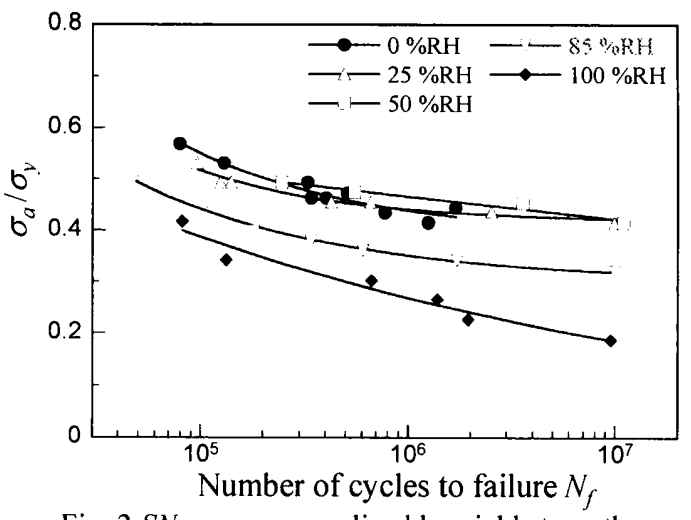

Fig. $2 S N$ curves normalized by yield strength.
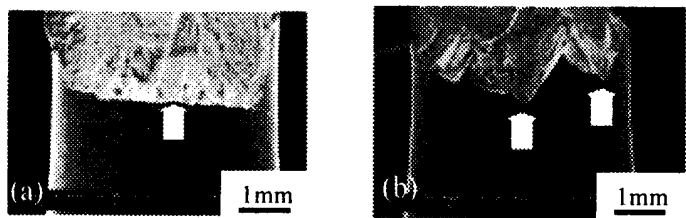

Fig. 3 Fracture manners at $280 \mathrm{MPa}$ (a) in $25 \% \mathrm{RH}$ and (b) in $85 \% \mathrm{RH}$.
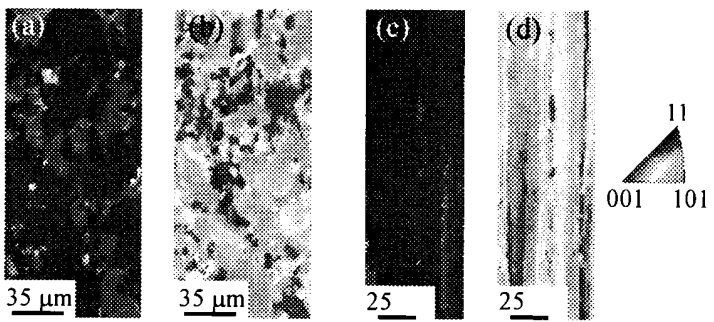

Fig. 4 IPF maps. (a) Normal and (b) parallel to transverse cross-section. (c) Parallel to extrusion direction and (d) normal to surface in longitudinal cross-section.

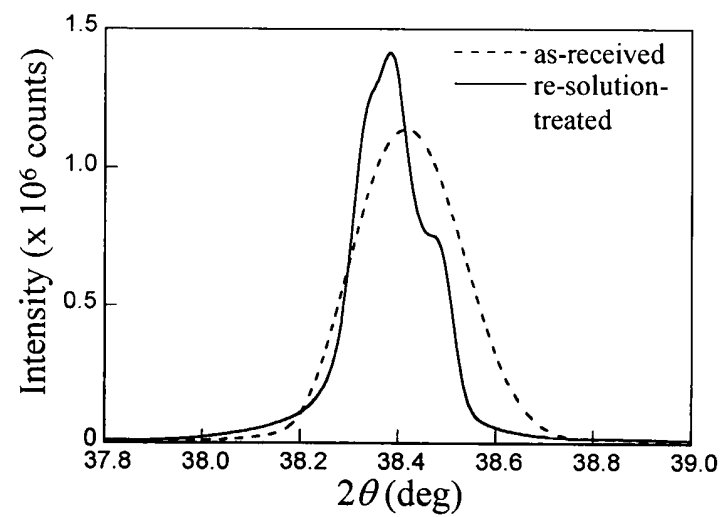

Fig. 5 XRD peaks of (111) reflection.

にXRD 解析を行い，<111>粒の優先的な配向により選択的 なすべりが生じやすいことがわかった。また結晶学的幾何 学を検討した結果，せん断形き裂の特徽をよく表すことが わかった．XRD 解析の結果からは，低転位密度の場合に集 合組織に従った選択的なすべり系の活動が示唆された。こ うした集合組織に従う選択的ずべりによりせん断形き裂を 伴う高湿度での疲労強度低下が生じると考えられる。

\section{文 献}

1) 仮屋孝二、他，時効硬化 $\mathrm{Al}$ 合金押出し材の回転曲げ疲労強度 に及ぼす大気湿度の影響，材料，60(2011) pp.339-344

2) 仮屋孝二, 高強度 $\mathrm{Al}$ 合金の疲労特性に及ぼす大気湿度の影 響に関する研究，博士論文（鹿児島大学，2012）。 